\title{
We adapt ... but is it good or bad? Locating the political ecology and social-ecological systems debate in reindeer herding in the Swedish Sub-Arctic
}

\author{
Gloria L. Gallardo F. ${ }^{\text {a }}$ \\ Fred Saunders ${ }^{\mathrm{b}}$ \\ Tatiana Sokolovac \\ Kristina Börebäck ${ }^{\mathrm{d}}$ \\ Frank van Laerhoven ${ }^{\mathrm{e}}$ \\ Suvi Kokko ${ }^{\mathrm{f}}$ \\ Magnus Tuvendal $^{\mathrm{d}}$ \\ ${ }^{\text {a }}$ Uppsala University, Sweden \\ b Södertörn University, Sweden \\ ${ }^{\mathrm{c}}$ Independent researcher \\ ${ }^{\mathrm{d}}$ Stockholm University, Sweden \\ ${ }^{\text {e }}$ Copernicus Institute of Sustainable Development, Utrecht University, Netherlands \\ ${ }^{\mathrm{f}}$ Swedish University of Agricultural Sciences, Sweden
}

\begin{abstract}
Reindeer herding (RDH) is a livelihood strategy deeply connected to Sami cultural tradition. This article explores the implications of two theoretical and methodological approaches for grasping complex socioenvironmental relationships of RDH in Subarctic Sweden. Based on joint fieldwork, two teams - one that aligns itself with political ecology (PE) and the other with social-ecological systems (SES) - compared PE and SES approaches of understanding RDH. Our purpose was twofold: 1) to describe the situation of Sami $\mathrm{RDH}$ through the lenses of PE and SES, exploring how the two approaches interpret the same empirical data; 2) to present an analytical comparison of the ontological and epistemological assumptions of this work, also inferring different courses of action to instigate change for the sustainability of RDH. Key informants from four sameby in the Kiruna region expressed strong support for the continuation of RDH as a cultural and

\footnotetext{
${ }^{1}$ Dr. Gloria L. Gallardo F., Centre for Sustainable Development, Uppsala University, Sweden. Email: gloria.gallardo "at" csduppsala.uu.se. Dr. Fred Saunders, School of Natural Sciences, Technology and Environmental Studies, Södertörn University, Sweden. Tatiana Sokolova, Freelance researcher in socio-environmental studies. Kristina Börebäck, Department of Education, Stockholm University, Sweden. Dr. Frank van Laerhoven, Copernicus Institute of Sustainable Development, Utrecht University, Netherlands. Suvi Kokko, Department of Economics, Swedish University of Agricultural Sciences, Sweden. Dr. Magnus Tuvendal, Stockholm Resilience Centre, Stockholm University, Sweden. Acknowledgements: We would like to first and foremost thank Sami community representatives (Table 1), for engaging with the research presented here in a generous, knowledgeable and forthright way. This also extends to those representatives from the Sami Parliament and other Sami organisations, who were also very generous with their time and knowledge. We acknowledge the Centre for Sustainable Development, Uppsala University for seeing the potential value of the research, as well as the Swedish Polar Secretary for the network support grant for our Polar network 'People, nature and sustainability network: environmental humanities, social and natural sciences perspectives on the development of the Arctic and Sub-Arctic region' (2013-2014), and for facilitating the stay of the Sami community representatives at the Polar Forum November 2014 in Stockholm. There are also numerous individuals, most important among them is H. Beach, who carefully read, commented on and engaged in discussions of previous iterations of this article, as did M. Kuschler. We acknowledge L. Eunice who participated in the first field visit to Abisko. We are also grateful to C. Jansson, former Director of the Abisko Scientific Research Station, for supporting the empirical work. In addition, we thank I. Berit for her hospitality and an anononmous informant for the inspiration for the title. We would also like to acknowledge those who were sceptical about our project, who provided us with reactions, not always positive, that suggested this project was worthwhile. Last we would like to thank the two anonymous reviewers and editor of JPE for their thoughtful and constructive comments that improved the article.
} 
economic practice. Concerns about the current situation raised by Sami representatives centered on the cumulative negative impacts on RDH from mining, forestry and tourism. PE and SES researchers offered dissimilar interpretations of the key aspects of the RDH socio-economic situation, namely: the nature and scale of RDH systems; the ubiquitous role of conflict; and conceptualizations of responses to changing socioenvironmental conditions. Due to these disparities, PE and SES analyses have radically divergent sociopolitical implications for what ought to be done to redress the current RDH situation.

Keywords: Reindeer herding, political ecology, social-ecological systems, resilience, interdisciplinary, ontological assumptions, conflicts/consensus, adaptation

\section{Résumé}

L'élevage de rennes $(\mathrm{RDH})$ est une stratégie de subsistance étroitement liée à la tradition culturelle sami. Cet article explore les implications de deux approches théoriques et méthodologiques pour saisir les relations socio-environnementales complexes de RDH dans la Suède Subarctique. Sur la base du travail sur le terrain, deux équipes - une qui s'harmonise avec l'écologie politique (PE) et l'autre avec les systèmes socioécologiques (SES) - ont comparé les approches PE et SES pour comprendre le RDH. Notre but était double: 1) décrire la situation de Sami RDH à travers les lentilles de PE et SES, en explorant comment les deux approches interprètent les mêmes données empiriques; 2) présenter une comparaison analytique des hypothèses ontologiques et épistémologiques de ce travail, en déduisant également différentes voies d'action pour instaurer un changement pour la durabilité de RDH. Les informateurs clés de quatre sameby dans la région de Kiruna ont fortement soutenu la poursuite de $\mathrm{RDH}$ en tant que pratique culturelle et économique. Les préoccupations concernant la situation actuelle soulevée par les représentants de Sami ont été centrées sur les effets négatifs cumulatifs sur le RDH des activités minières, forestières et touristiques. Les chercheurs de PE et de SES ont proposé des interprétations différentes des aspects clés de la situation socioéconomique de RDH: la nature et l'échelle des systèmes RDH; Le rôle omniprésent du conflit; Et les conceptualisations des réponses à l'évolution des conditions socio-environnementales. En raison de ces disparités, les analyses PE et SES ont des implications socio-politiques radicalement divergentes pour ce qui devrait être fait pour remédier à la situation actuelle de RDH.

Mots-clés: élevage de rennes, écologie politique, systèmes socio-écologiques, résilience, interdisciplinarité, hypothèses ontologiques, conflits/consensus, adaptation

\section{Resumen}

El pastoreo de renos es una estrategia de sustento profundamente arraigada en la tradición cultural del pueblo sami. Este artículo explora las implicancias de dos enfoques teóricos y metodológicos, para comprender las complejas relaciones socio-ambientales de esta actividad socioeconómica en el sub-ártico de Suecia. Basados en un trabajo de campo conjunto, dos equipos - uno que se alinea con la ecología política (PE) y el otro con los sistemas socio-ecológicos (SES) - realizan un estudio comparativo, con el doble propósito de: 1) describir la situación actual del pastoreo de renos, explorando como se interpretan los mismos datos empíricos desde ambos enfoques (PE y SES); 2) presentar una comparación analítica de los supuestos ontológicos y epistemológicos de este trabajo, infiriendo también diferentes cursos de acción para fomentar el cambio hacia un pastoreo de renos más sustentable. Los informantes clave de cuatro comunidades sami de la región de Kiruna expresaron su firme respaldo a la continuación del pastoreo de renos como práctica cultural y económica. Sus preocupaciones sobre la situación actual se centraron en los impactos negativos acumulados de la minería, la silvicultura y el turismo sobre esta actividad socioeconómica ancestral. Los investigadores de PE y SES ofrecieron diferentes interpretaciones de los aspectos clave de la situación del pastoreo de renos; a saber: la naturaleza y la escala del sistema; el papel omnipresente de los conflictos; y las conceptualizaciones de las respuestas a las cambiantes condiciones socio-ambientales. Debido a estas disparidades, los análisis de PE y SES tienen implicaciones sociopolíticas radicalmente divergentes sobre lo que se debería hacer para remediar la actual situación del pastoreo de renos del pueblo sami.

Palabras clave: pastoreo de renos, ecología política, sistemas socio-ecológicos, resiliencia, interdisciplinaridad, supuestos ontológicos, conflictos/consenso, adaptación 


\section{Introduction}

There have been numerous forays contesting the relative merits of political ecology (PE) and socialecological systems approach (SES) to understand human-nature relationships (Armitage 2007; Brown 2013; Cote and Nightingale 2011; CSD Conference 2013; Jagers et al. 2012; Nadasdy 2007; Peterson and Hornborg 2012; Widgren 2012). Some contributions to what we call the PE:SES debate take a positive view by arguing that there are synergies to be reaped by combining the two approaches (Armitage 2007), while others (usually of the PE persuasion) take a more critical stance that hones in on what are seen as flaws or shortfalls in the opposing approach (Nadasdy 2007; Olsson et al. 2015).

The contention between PE and SES pivots around the political ecology claim that SES studies privilege ecological concepts in analyzing social-ecological systems, with the implication that such studies are largely inattentive to the role of power in shaping human-nature relationships (Hornborg 2009; Widgren 2012). Furthermore, critics of SES point out that its studies commonly fail to "unpack normative questions such as 'resilience of what?' and 'for whom?' when applied to the social realm" (Cote and Nightingale 2011: 479; White and O'Hare 2014). Some scholars point out the differences in objectives between the two approaches (Jerneck et al. 2011). They argue that SES is a politically conservative approach as its problemsolving focus seeks to enhance the efficiency or functionality of the existing institutional framework (a managerial approach) (Kull and Rangan 2016; Schoon et al. 2015), whereas PE is aligned with critical research that aims to reveal the way that local conditions are produced through interaction with the global political economy in which it is embedded. PE in this sense is explicitly normative, seeking to connect emancipatory interests, social contextual understanding with scientific knowledge. In keeping with its roots and proclivities, the PE engagement in this debate has tended to take a more critical view of SES work than vice versa (Kull and Rangan 2016), although there have been exceptions where well-known scholars have sought to build bridges between the two approaches (see Adger 2006; Brown 2014; Leach 2008; Peterson 2000). While it is important to note that perspectives being expressed in either body of work are not uniform, arguably, they both display tendencies rooted in their respective epistemological and ontological assumptions (Brown 2014; Kull and Rangan 2016).

This research contributes to this on-going discussion by assembling a multidisciplinary team of researchers, with experience and expertise in both PE and SES, to conduct an empirical study on reindeer herding (RDH) in Subarctic Sweden. Norrbotten County (Norrbottenslän), where the study takes place, is experiencing significant economic development in areas that have been traditionally been used for RDH. Historically, during the 1950s and 1960s, Norrbotten County experienced strong economic and infrastructure development, including hydropower (Össbo and Lantto 2011), large-scale forestry, mining, defense activities, and tourism (Lundmark 1998). Many of these activities directly interfered with reindeer (Rangifer tarandus) migration routes and pastures (Beach 1981; Cramér 2003; Lundmark 1998). The County faces a unique set of challenges and political legacies, thereby providing an insightful setting to compare how PE and SES approaches frame human-nature relationships of RDH.

The purpose of the article is to 1) describe Sami RDH perceptions on how factors such as mining, forestry and other ongoing economic activities are impacting on $\mathrm{RDH}, 2$ ) present empirical analyses from a $\mathrm{PE}$ and SES understanding of RDH and 3) perform a meta-analysis of PE and SES approaches through reflection on the RDH case. A strong motivating force, which forged the participation of researchers in this project, was to explore PE and SES in close collaboration through the structure of an interdisciplinary empirically-based project, where opportunities would arise for discussion and reflection between researchers at all stages of the research process.

\section{Political ecology and social-ecological systems}

\section{A political ecology framing}

PE can be regarded as a multi-faceted framework centrally concerned with examining how political and economic power is exercised to marginalize and dispossess people of their land, resources and/or livelihoods. The crucial focus is on revealing power relations among actors over use, access and control of 
resources. Contemporaneous and spatially located conflicts over resources are framed in the broader context of historical relations and political economy (Kull and Rangan 2016; Peet et al. 2011). PE conceptualizes conflicts as inherent in social systems, and grounded in unequal power relations where the divergent "interests, characteristics and actions of different types of actors" clash (Bryant and Bailey 1997: 23). Situated within wider environmental and socio-political contexts, conflict then becomes an outcome of the interactions of different actors pursuing aims and interests that are commonly at variance. Trying to redress resource conflicts through the same institutional arrangements that reproduce power relations is seen as problematic. From a PE perspective, what is required in such situations are more substantive interventions to reconfigure power relations.

According to Martinez Alier "Power is sometimes a brute force, sometimes it is the ability to set the agenda and to impose decision procedures that exclude whole classes of people" (2010: 7). Power expressed through political and economic relations manifests as relations of production, where for example global market actors, with the support of the state, expropriate natural resources that are already claimed and are used to support local livelihoods (Khan 2013). Important in such accounts is to not lose sight of the way local politics are played out regarding access to, and control over, resources (Bryant 1998: 82). This remains the central empirical concern for PE. This focus on empirical practices, however, needs to be located in an examination of the overall relationship between markets, state authority, local power and environmental change. In revealing the complexity and uneven power relations in this way, a PE approach seeks to disclose and challenge the taken-for-granted apolitical character of existing (often technocratic) state/market institutions that direct and reproduce resource access, use and control (Heynen et al. 2007). This is particularly pertinent if such institutions work to lock people into situations of environmental, cultural, political and/or economic marginalization through such acts as enclosures of the commons, adverse incorporation and means of dispossession (Hall et al. 2015). Revealing the way that hegemonic discourses of economic growth are institutionalized can expose obscured or marginalized heterogeneous problem framings, asymmetrical power relationships and incompatibility of interests. Extremely salient to this article, in line with this PE tradition, is a focus on how political (state) and economic (market) power coalesces to progressively enclose commons by dispossessing 'locals' and placing rents into the hands of diverse market actors operating at multiple scales. Essential to this perspective is to examine the role of the state in fostering the broader historical trajectory of socio-economic change.

\section{Social-ecological systems}

Social-ecological systems (SES) are defined as "a multi-scale pattern of resource use around which humans have organized themselves in a particular social structure" (Resilience Alliance 2015). The SES approach - underpinned by resilience thinking and neo-institutional theory - applies a system-analytical perspective. This implies that analytical attention is shifted from the causal forces at work on individual system components - and the detailed implication of each local interaction - to the behavior of the system as a whole. Anthropologist Stephen Lansing points out that the resulting focus on global patterns at the system level, come at a cost: "The observer must usually give up the hope of understanding the workings of causation at the level of individual elements" (Lansing 2003:1985). The SES approach's central tenet is that systems are characterized by constant change that is not understood by analyzing its components in isolation but rather by the relationship between building blocks (Rogers et al. 2013). Of particular interest is the interaction between social and ecological subsystems (Cumming et al. 2006; Duraiappah et al. 2014). System level change can be prompted by internal processes, inherent to both social and ecological subsystems, (Holling 1986; Westley et al. 2013) or triggered by exogenous events and framed in terms of disturbances (Carpenter et al. 2001), or perturbations (Adger 2000). Disturbances may affect a system's identity, defined by system level properties related with functions, structures and feedbacks. Examining components, relations, and responses in this way offers insights into 1) a system's identity, 2) the expected effect of disturbances on a system's identity, and 3) the expected effect of users' responses to disturbances. Thus, central to this approach is the concept of resilience, or "...the capacity of a system to absorb disturbance and reorganize while undergoing change so as to still retain essentially the same function, structure and feedbacks..." (Folke et al. 2010: 1). 
From the literature, key variables affecting the sustainable functioning of a SES are: differentiated knowledge generation and dissemination resulting in (social) learning, the existence of conflict resolution mechanisms, and institutions for coordination (i.e. institutions that provide guidance in decision-making with relatively low transaction costs) (e.g. Janssen et al. 2006; Pahl-Wostl 2009; Sandström and Rova 2010). The (social) interactions that the SES framework focuses on include, among other things, information sharing among users and deliberation processes, which require trust (e.g. Ostrom and Walker 2003). This view posits that conflict resolution is enhanced by negotiation, but if this is not possible, deep conflicts may be a key implicating factor in a dysfunctional system.

There has been much criticism (commonly from PE scholars) that the resilience thinking underpinning SES elides questions of power and conflict (Kull and Rangan 2016). Brown (2014), a scholar who bridges SES and PE, has thoroughly responded to this critique by highlighting the recent social turn in resilience related literature, which includes increased attention given to power. Biermann (2016) also addresses issues of power in a nuanced and focused way, when responding to criticism about adopting an overly simplistic and globalized view on human agency in conceptualising the Anthropocene. While there are continuing tensions among different scholars on the way power and conflict are variably handled (see Hornborg 2017), there is an increasing trend and deeper focus in the SES literature on the politics of environmental change.

\section{Methodology}

The four samebyar ${ }^{2}$ we focus on in this article are: Gabna, Talma, Laevas and Saarivuoma in Norrbotten County (see Figure 2). The four samebyar share a geographical proximity, operate under similar social and environmental conditions, and experience similar challenges in land use.

Using semi-structured interviews, primary data was gathered by the multidisciplinary team of PE and SES researchers in December 2012, March 2013, and November 2014. Interviews were conducted in person and by telephone. Informants included reindeer herders from the four sambyar mentioned above as well as other reindeer herding related actors (see Table 1). We also draw on secondary data, including books, peerreviewed articles on Sami history, $\mathrm{RDH}$, and scientific reports pertinent to the objectives of this study.

The initial set of interview questions was open-ended and deliberately designed to identify significant and contemporary experiences and herders' concerns. The key questions that were asked revolved around the following issues: the most significant changes that have affected reindeer herding over the past 20-30 years; the causes of these changes and their longer-term consequences for reindeer herders; what was problematic and what worked under the current management regime as well as what changes were needed, who should undertake them and how could they be enacted. The research group was conscious of formulating the questions 'neutrally' to minimize the possibility of unwittingly imbuing them with PE or SES preconceptions. The analysis of interview data was undertaken by the PE and SES researchers independently of each other, drawing on concepts from PE and SES elaborated earlier. As the ambition was to compare the analyses of both approaches, the two clusters of researchers commented on each other's interpretations. This meant moving beyond a mere comparison in relation to interpretations of the empirical material of $\mathrm{RDH}$ to examination of the respective ontological and epistemological assumptions of both approaches.

The resulting data from factors impacting on RDH is listed in Table 3, according to our informants' accounts. This information was triangulated and validated with GIS maps from The Sami Parliament ${ }^{3}$ (sametinget) (courtesy of P. Benson, GIS and land-use officer, 2013). All the sameby informants raised their

\footnotetext{
${ }^{2}$ A sameby is a financial and administrative economic association, which organises reindeer herding in a specific geographical area. A sameby can nowadays be described as a multidimensional concept which can designate: a Sami community; a geographical reindeer pasture district; a Sami reindeer foraging area; a cooperative working group of reindeer herders which generates economic benefits related to reindeer herding to its members and a judicial person (Beach 1981; Green 2009). There are 51 samebyar in Sweden that practice RDH (The Sami Parliament 2015). The current Swedish Reindeer Herding Act stipulates that a sameby - as a financial and administrative economic association - cannot engage in any other economic activities other than herding (SFS 1993: 36). This does not hinder individual members, or groups of them, initiating and participating in other activities outside the sameby or selling their labor on the market.

${ }^{3}$ The Sami Parliament is the central managing and governing authority for reindeer herding and Sami issues, as well as a Swedish national authority, and a body elected by Sami (Sami Parliament 2015; SFS 1992: 1433).
} 
main concerns in different orders of significance (see cases below). The ordinal estimation of the degree of impact by each type of impacting activity was undertaken through a second step with two reindeer herders from Gabna and Laevas in November 2014. Telephone interviews with the presidents of Talma and Saarivuoma samebyar were conducted during November and December 2014 to get views on the rankings. Table 1 specifies key informants, their position or role, as well as the date and place of the interviews.

To gain additional understanding of reindeer herding from a range of perspectives two members of the research team attended the following conference as observers: Knowledge Conference for a Magnificent Mountain Landscape (Kunskapskonferens för Storslagen Fjällmiljö), which was organized by the Swedish Environmental Protection Agency (EPA) in Abisko, 13-15 March 2013 (hereafter called NVV Abisko Conference 2013). At this conference, government agencies, academics and several representatives of samebyar discussed the challenges for sustainable development of the Swedish mountain landscape. ${ }^{4}$

\begin{tabular}{|c|c|c|}
\hline Key Informants & Date & Place \\
\hline Allas, J., President Talma sameby & $\begin{array}{l}2012-12-07 \\
2014-12-02\end{array}$ & $\begin{array}{l}\text { Kiruna } \\
\text { Phone }\end{array}$ \\
\hline Niia, E. A., Reindeer herder Gabna sameby & 2012-12-07 & Kiruna \\
\hline Kuhmunen, L. E. President Gabna sameby & \begin{tabular}{|l|} 
2013-03-19 \\
2014-11-06 and 07 \\
\end{tabular} & \begin{tabular}{|l|} 
Phone \\
Stockholm
\end{tabular} \\
\hline Labba, P., President Saarivuoma sameby & 2013-03-14 & Kiruna \\
\hline $\begin{array}{l}\text { Nutti, P-A. Incoming President Saarivuoma } \\
\text { sameby }\end{array}$ & $\begin{array}{l}2013-06-07 \\
2014-11-26 \\
\end{array}$ & $\begin{array}{l}\text { Phone } \\
\text { Phone }\end{array}$ \\
\hline $\begin{array}{l}\text { Partapuoli, H-G. Member Laevas sameby } \\
\text { board }\end{array}$ & \begin{tabular}{|l|} 
2013-03-14; \\
2014-11-06 and 07 \\
\end{tabular} & \begin{tabular}{|l|} 
Laevas \\
Stockholm \\
\end{tabular} \\
\hline Huuva, E., President Laevas sameby & 2013-03-20 & Phone \\
\hline $\begin{array}{l}\text { Spouse of reindeer owner from Laevas } \\
\text { (anonymous) }\end{array}$ & 2013-12-06 & Laevas \\
\hline \multicolumn{3}{|l|}{ Others } \\
\hline $\begin{array}{l}\text { P. Benson GIS and land-use officer, The Sami } \\
\text { Parliament }\end{array}$ & 2013-12-06 & Kiruna \\
\hline $\begin{array}{l}\text { T. Kuhmunen, GIS-operator, The Sami } \\
\text { Parliament }\end{array}$ & 2013 and 2014 & Phone and Mails \\
\hline V. Håkansson, Chairperson Sami Fund & 2015-07-09 & Phone \\
\hline \multicolumn{3}{|c|}{$\begin{array}{l}\text { Knowledge Conference for a magnificent mountain landscape (Kunskapskonferens för Storslagen } \\
\text { fjällmiljö), organized by the Swedish Environmental Protection Agency (EPA; Naturvårdsverket, } \\
\text { NVV) in Abisko, 13-15 March } 2013\end{array}$} \\
\hline $\begin{array}{l}\text { Jonsson, Kristina. Expert Mountain } \\
\text { Management Nature Protection Unit, } \\
\text { Länsstyrelsen i Jämtland (County } \\
\text { Administrative Board, Jämtland. }\end{array}$ & 2013 & Oral presentation \\
\hline $\begin{array}{l}\text { Joudga, Leif, Skogsstyrelse (Swedish Forest } \\
\text { Agency) }\end{array}$ & 2013 & $\begin{array}{l}\text { PowerPoint presentation: } \\
\text { Renbruksplaner - planerings- } \\
\text { verktyg för samebyar. }\end{array}$ \\
\hline NVV (EPA) & 2013 & $\begin{array}{l}\text { PowerPoint presentation: } \\
\text { Naturturism som basnäring. }\end{array}$ \\
\hline
\end{tabular}

Table 1: List of key informants.

\footnotetext{
${ }^{4}$ The use of this term is in line with the Anglophone understanding, where landscape means scenery; while "landskap in the Nordic languages was originaly more connected with the territory, its customary laws, and its social order, and only secondary with scenery" (Widgren 2015: 201).
} 
While the ambition of this article is to conduct an experiment of sorts, where we apply SES and PE to the 'same data set' to ascertain similarities and differences in analyses, some would see limitations to this approach. If the data collection had been designed and collected separately by SES resilience and PE scholars, the finding would most probably be different, but the idea was precisely to apply the two lenses to the same data to reveal the similarities and differences of both approaches. Acknowledging that this approach limits the scope of each lens, the novelty of our experiment consists in drawing out and juxtaposing underpinning assumptions and dispositions in both PE and SES.

\section{Perceptions and expressions in a contested landscape: Norrbotten County}

A succinct review of RDH history (see Figure 1) shows a clear pattern of increasing encroachments and expropriation of the RDH commons through a continuous process of accumulation by dispossession. In 1602, the Swedish Crown introduced a tax policy which entailed collection of tax in reindeer and fish (instead of in furs, as it was previously). It is likely that this tax burden triggered a transition from hunting and fishing as predominant economic activities toward semi-nomadic RDH (Holmbäck 1922; Lundmark 1998). At the end of the 17th century, the Swedish State started to encourage settlement in the North. The 1749 settlement regulation was aimed at protecting the economic interests of the Sami (Beach 1981; Holmbäck 1922; Lundmark 1998), however, conflicts arose between the two groups, as settlers hunted and fished in prohibited areas, and reindeer herds disrupted settlers' hay production (Sköld 2011). There was a clear tendency in these conflicts for the authorities to side with the settlers (Cramer 2003).

In 1868, the cultivation borderline (odlingsgränsen) was moved higher up in the mountains, which had the effect of decreasing the RDH area (Beach 1981; Cramer 2003). West of the 1868 cultivation border, pastoral land was to be reserved for reindeer herders, which also included rights to fishing, wood and small game hunting (Beach 1981; Holmbäck 1922). However, the intent of these rights was not converted into practice. In Västerbotten (one part of Norrbotten County), 131 new settlements were established west of the cultivation borderline, many of which were established after the Parliament had taken a decision on the new border (Holmbäck 1922: 64; Lundmark 1998: 79-80).

In Lapland, Sami's right to tax-land was systematically abolished in 1870 (Beach 1981; Hafström 1981; Holmbäck 1922; Lundmark 1998). This had previously been an important right to the land that was recognized and tied to specific persons or groups of people. The pasture law introduced in 1886 secured the use right to pasture land as a common right of specific Sami communities (later sameby). Under this law, RDH was not considered to be an economic activity and therefore not taxed (Beach 1981: 79, 362; Lundmark 1998: 94).

One of the later examples of encroachment was that the Swedish state took away decision-making rights over small wild animal hunting and fishing from samebyar the same day that the Sami Parliament was established in 1993. The Girjas sameby recently (in 2016) won a case through the Gällivare District Court which awarded them exclusive rights for small game hunting and fishing in the sameby (Dagens Nyheter 2016).

Norrbotten County - the regional location of the four samebyar examined in this study - has good road infrastructure and is easily accessible by domestic and direct international flights, which provides advantages in supporting tourism and business activities. This ease of accessibility (for a seemingly remote location) is most likely contributing to the current dynamics of Norrbotten as a contested landscape, where multiple competing interests are at play. According to the Swedish National Sami Association (Svenska Samerernas Riksförbund, SSR) ${ }^{5}$, Sami reindeer herders have conducted reindeer husbandry on Sami land since time immemorial, and demand ownership rights to the land, water and natural resources (SSR letter to Minister of Rural Affairs 2012), whereas the Swedish State only recognizes use rights (SOU 2006). Unlike Norway, Sweden has not yet ratified the ILO Convention C169 concerning Indigenous and Tribal Peoples in

\footnotetext{
${ }^{5}$ The SSR is a politically independent association aiming to represent and promote the Swedish Sami's economic, social, legal, administrative and cultural interests with special emphasis on the sustainable development of reindeer herding livelihoods (SSR 2013).
} 
Independent Countries from 1989 (Semb 2012; Sköld 2011).

\section{A Timeline of Significant Events for Reindeer Herding}

\begin{tabular}{|c|c|}
\hline & \\
\hline $\begin{array}{r}1547 \\
\text { Sami start to pay tax directly to the Crown. }\end{array}$ & 1602 \\
\hline Sam staut to pay tax directly to the Crown. & Changed tax policy. Sami start paying taxes in reindeer \& \\
\hline $\begin{array}{rr}\text { c.1607 } \\
\end{array}$ & more fish. \\
\hline Skin trade diminishes. Sami cannot afford the tax burden. & \\
\hline Migration to Norway. Change to semi-nomadism. & 1673 \\
\hline 1695 & Colonisation decree allows settle \\
\hline Taxes imposed on the community and not on individuals. & 1721 \\
\hline 1749 & Interests for agriculture in Sami land increase. Settlers have \\
\hline $\begin{array}{l}\text { The border between Norr- and Vasterbotten and Sami land is } \\
\text { established. The Sami have a strong legal position compared }\end{array}$ & no right to hunt and fish beyond five $\mathrm{km}$ from their homes. \\
\hline with peasants and settlers. & Mid 18 th c. \\
\hline $\begin{array}{l}\text { Mid 18th-mid 19th c. } \\
80 \text { more settlements in today's Lapland. Economic crisis } \\
\text { among Sami. Sami start taking each other to courts due to } \\
\text { land conflicts. Sami lose their key trade position. }\end{array}$ & $\begin{array}{l}\text { Sami free trade, also stating that the Sami own their land. } \\
\text { Large-scale nomadism gives the Sami a strong position in the } \\
\text { market. }\end{array}$ \\
\hline & 1785 \\
\hline $\begin{array}{r}1789 \\
\text { Peasants (including Sami) in Sweden secure their inheritance } \\
\text { rights within the state land. }\end{array}$ & $\begin{array}{l}\text { Lawsuits increase. Courts judge in the beginning in favour of } \\
\text { the Sami with respect to hunting and fishing. Later Sami lose } \\
\text { their rights to their taxed land in local courts. }\end{array}$ \\
\hline 1820 & End 18th c. \\
\hline $\begin{array}{l}\text { Jamtland \& Härjedalen: the Crown distributes forestry land to } \\
\text { settlers, (avvittring); Sami lose pasture land. }\end{array}$ & $\begin{array}{l}\text { Colonisation strengthens. Settlements increase to } 343 \text {. } \\
\text { Population increases four times between } 1800 \text { \& } 1890 \text {. }\end{array}$ \\
\hline 1870 & 1860 \\
\hline $\begin{array}{l}\text { Avvittring starts in Lappland. The agricultural border is de- } \\
\text { fined in Norr- \& Vasterbotten, giving the Sami the land right } \\
\text { above the border and grazing right below. }\end{array}$ & $\begin{array}{l}\text { The King curtails Sami rights in Jämtland. Only grazing } \\
\text { animals, cut trees, hunt and fish for own need on mountain } \\
\text { tax land is allowed. Sami protest. Crown recognized later } \\
\text { Sami rights to pasture in private land without paying the }\end{array}$ \\
\hline 1886 & landowner. Sami's right to tax land is abolished in Lappland. \\
\hline $\begin{array}{l}\text { New pasture law: the Sami lose right to own land and are } \\
\text { divided in communities to perform family reindeer herding }\end{array}$ & \\
\hline in State pasture land. The Sami are put under guardianship & Debate whether Sami not having reindeers should belong \\
\hline of bailiffs (fogdar). Pasture right not considered an economic & the Sami communities. \\
\hline $\begin{array}{l}\text { asset, and thus not taxed and therefore not giving the Sami the } \\
\text { right to vote. }\end{array}$ & 1928 \\
\hline $\begin{array}{l}1950-60 \mathrm{~s} \\
\text { Hydropower stations are being built in the Lapland } \\
\text { Large scale forestry, mining and tourism follows. }\end{array}$ & $\begin{array}{l}\text { New reindeer pasture law (still in place). Sami reindeer } \\
\text { herders legally distinguished from non-Sami reindeer herders, } \\
\text { reducing the latter group' eligibility to exercise this activity. }\end{array}$ \\
\hline & 1961 \\
\hline 1966 & The Sami communities become legal persons, being able to \\
\hline $\begin{array}{l}\text { The Sami take the Swedish State to the court to secure their } \\
\text { right to pasture. }\end{array}$ & take on a lawsuit (ex. due to encroachments) \\
\hline & $\begin{array}{l}\text { End of } 1960 \mathrm{~s} \\
\text { Large-scale forestry exploitation starts. }\end{array}$ \\
\hline n right; & 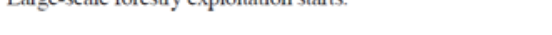 \\
\hline the 1928 reindeer herding right is the one till being & 1981 \\
\hline valid. & $\begin{array}{l}\text { The Sami lose after } 15 \text { years the lawsuit against the State } \\
\text { which started in } 1966 \text {. }\end{array}$ \\
\hline 1988 & \\
\hline Compensation for encroachment is subject to tax as a busi- & 1993 \\
\hline ness revenue. & $\begin{array}{l}\text { The Sami Parliament is established. The same day, the State } \\
\text { confiscates from the Sami their exclusivity to small wild }\end{array}$ \\
\hline 1996 & hunting. \\
\hline $\begin{array}{l}\text { The Sami lose a lawsuit; a court declares that the Sami had no } \\
\text { customary right to winter pasture in certain part of Härjedalen. }\end{array}$ & \\
\hline
\end{tabular}

Figure 1: A timeline of significant events for reindeer herding.

In 2012, NVV stated that "Reindeer herding is a prerequisite for magnificent graze-characterized mountain landscape. However, the reindeer's need of large areas will come in conflict with the need for facilities for outdoor activities and mineral mining" (NVV 2012, our italics). Preserving this mountain area is one of the Swedish environmental objectives. It is referred to as the Magnificent Mountain Landscape: "The pristine character of the mountain environment must be largely preserved ... Particularly valuable areas must be protected from encroachment and other disturbance. This objective is intended to be achieved within one generation" (NVV 2015, our italics). NVV also states that: 
Continued reindeer herding, together with other forms of livestock rearing, is needed to maintain an extensive mountain landscape, characterized by grazing and offering habitats for many different species. At the same time, the reindeer sector's need for large, continuous grazing areas has to be balanced against the need for facilities for outdoor recreation, naturebased tourism, wind power and mineral extraction. Growth in tourism, more off-road vehicles and increasing interest in development in mountain areas could create difficulties for reindeer herders, thereby eroding the benefits which grazing has in terms of biodiversity. Another conflict is over the size of predator populations, which affect reindeer husbandry in several ways. (NVV 2015, our italics)

Despite these ambitions, and the environmental objective of landscape protection, there are numerous ongoing activities including large-scale extraction, infrastructure development and recreation (NVV 2015). There is a clause in the law, associated with the Environmental Code to protect the designated reindeer herding areas from development action that significantly 'impedes' them. Application of the clause in each case is considered in the context of other competing national interests of socio-economic importance. For example, Sweden is by far the largest iron ore producer in the EU and is also among the foremost producers of base and precious metals (Geological Survey of Sweden 2017). ${ }^{6}$ The importance and priority accorded to this sector is underlined by the government's expectation that the number of mines will increase from 16 to 50 by 2030 (Swedish Ministry of Enterprise, Energy and Communication 2013:11). The Swedish national strategy for 2020 regarding the hospitality industry aims to double tourism consumption by 2020 (NVV Abisko Conference 2013; Västerbotten Investment Agency 2015). Given its emphasis on nature-based tourism, it can be expected that this type of tourism in the mountain landscape of Northern Sweden/Sápmi land will grow considerably.

As seen above, both the Swedish Parliament and NVV use the term encroachment (intrång) to describe conflicting human-human and human-nature relationships. This expression is also used by researchers in Sweden to describe impacts of the various activities that have expanded onto RDH grazing land (Beach 1981: 11, 31, 225, 237; Lundmark 1998: 124; Sköld 2011: 5, 10, 14). In Holmbäck's Governmental Official Investigation, from 1922, the term encroachment is used in relation to disputes between herders and settlers and to denote herders' encroachment on settler's land (Holmbäck 1922: 58). Karlsson (2015) writes systematically about threats (hot). In the questionnaire conducted by Statistics Sweden on behalf of SSR which is an appendix in Karlsson's doctoral thesis, the more neutral term störningar (perturbation, alteration, disturbance) is used to refer to activities impacting on RDH. Encroachment, for the PE researchers in this project, is relational, connecting the 'encroacher' with the 'encroached' in a way that is detrimental for the latter. ${ }^{7}$ The SES researchers use 'disturbance' to refer to the same process.

\section{The cases}

The four samebyar selected for this study, Laevas, Gabna, Talma and Saarivuoma are located west of the cultivation border (Figure 2, blue line). All of these samebyar possess year-round grazing rights west of the cultivation border and winter grazing rights to the eastern lapland border (lappmarksgränsen) (red line). The size of herds and the amount of members in thesamebyar vary (see Table 2).

\footnotetext{
${ }^{6}$ Mines are underground and open pits, but both involve substantial landscape scale changes because of their scale and related processing requirements, waste disposal and supportive ancilliary infrastructure.

${ }^{7}$ The verb encroach has it origin in the Middle English encrochen to get, seize, from Anglo-French encrocher, from en- + croc, a croche hook. The first known use of the verb is from 1528 (Merriam-Webster Dictionary 2015). To encroach means "to gradually take or begin to use or affect something that belongs to someone else or that someone else is using" or also "to enter by gradual steps or by stealth into the possessions or rights of another." Synonyms of this terms are: trespass, intrusion, intromission and invasion (Dictionary Reference 2015; Merriam-Webster Dictionary 2015).
} 


\section{Saarivuoma sameby}

No mines operate in Saarivuoma's territory although prospecting has taken place (Labba, Interview). The area of main interest for mining is located in the core of Saarivuoma's reindeer pastureland, where reindeer gather during spring and autumn. Labba was of the view that the 'government' has shown a strong preference for mining development over reindeer herding. "When it comes to mining, we have nothing to say; the Mining Inspectorate of Sweden ${ }^{8}$ (Bergstaten) will define mining as a national interest that is more valuable than reindeer herding" (Labba, Interview). He went on to say: "Would an ore deposit be discovered in the area, the mining development would pose an existential threat to reindeer husbandry in Saarivuoma, being a death-blow to the sameby."

The Esrange Space Centre ${ }^{9}$ is located within Saarivuoma's pastureland. Saarivuoma receives compensation through the Sami Fund as the Centre occupies grazing areas (The Sami Parliamant 2013). It also receives a small compensation from the Centre for activities that disturb RDH (Sveriges Radio 2013). The County Administrative Board has recently stopped further prospecting of ore deposits in the area, however not out of concern for reindeer herding but due to interference or incompatibility with the operations of the space centre's operations (Labba, Interview). In Labba's opinion the chances of avoiding development of mining in the community is made stronger by Esrange's presence.

Labba discussed how tourism is another activity that encroaches on reindeer herding pastures in Saarivuoma, due to construction of recreational cottages and small holiday villages, which attract tourists with snowmobile tours and illegal "off-road" driving, disturbing grazing reindeer. Dogsledding is another tourist activity that disturbs reindeer herds which, "are already in a weakened and vulnerable state due to the scarcity of forage in late winter."

In addition, clear-cutting of forests encroaches on reindeer husbandry. Labba clarified that in Saarivuoma, part of the forestland is not private property but the common property of settlers and/or Sami people. The logs are processed by one of the main logging companies in Sweden. ${ }^{10}$ The area is required to be reforested in accordance with Swedish law (Labba, Interview; SFS 1979: 429). Saarivuoma has developed reindeer management plans that indicate the most valuable seasonal reindeer pastures and long-term land-use considerations. But these plans are experienced as problematic:

...because in the wrong hands, like the logging companies, this might have consequences on how the reindeer pasture is defined in the future. They [Swedish Forestry Agency] say that we [Saarivuoma reindeer herders] own the information [about reindeer management plans], but I am scared and I do not really trust them on this. (Labba, Interview)

The objective of the reindeer management plans financed by the Swedish Forest Agency (2013) is to improve the basis for operation of RDH, the basis for consultation, and the basis for communication with other land users. Most of samebyar have adopted such plans (Joudga, Presentation 2013).

Lastly, Labba described the threat that predators pose to reindeer husbandry in Saarivuoma. Despite monitoring the increases in populations of wolverines, wolves and bears in the area, the County Administrative Board does not share the information with the sameby. The increasing bear population has become a problem for Saarivuoma since, "bears take half of the new born reindeer calves each year when they wake from hibernation in the spring" (Labba, Interview).

\footnotetext{
${ }^{8}$ The Mining Inspectorate of Sweden is the official body in Sweden responsible for issuing permits for prospecting and exploitation concessions (The Mining Inspectorate of Sweden 2016).

${ }^{9}$ The Esrange Space Centre provides launching facilities for sounding rockets (for research) and stratospheric balloons and functions as a civil ground station for satellites. ESA/EASP member states (France, Germany, Norway, Switzerland, Sweden) have priority use of the centre (SSC 2017).

${ }^{10}$ Among those companies involved are: Norrskog (a forest-owner cooperative), Stora Enso (an international forest company), and Sveaskog (a state-owned forest company).
} 


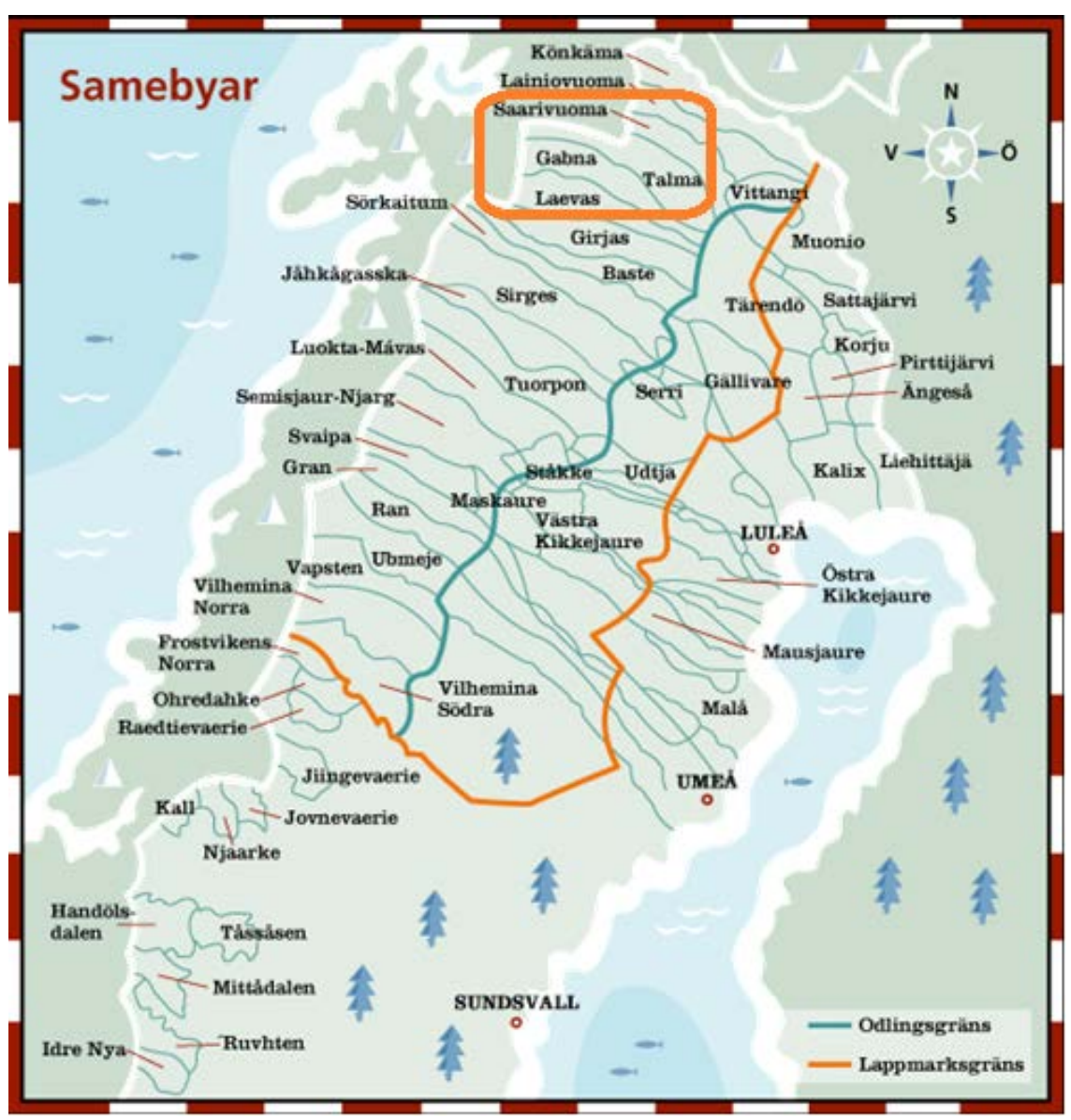

Figure 2: Map of samebyar in Sweden adapted from Sami Parliament 2012.

\begin{tabular}{|l|r|r|r|r|}
\hline & \multicolumn{1}{|c|}{ Laevas } & \multicolumn{1}{c|}{ Gabna } & \multicolumn{1}{c|}{ Talma } & \multicolumn{1}{c|}{ Saarivuoma } \\
\hline $\begin{array}{l}\text { Members (ca.)/ heads of } \\
\text { extended families }\end{array}$ & $60 / 17$ & $101 / 11$ & $120 / 31$ & $330 / 64$ \\
\hline No. of reindeer (ca.) & 8,500 & $<6,500$ & 7,000 & 58 \\
\hline $\begin{array}{l}\text { No. of reindeer/reindeer } \\
\text { owner }\end{array}$ & 142 & 64 & 425,100 & 39 \\
\hline Area in ha. (within Sweden) & 463,000 & 366,600 & 0.016 & 0.037 \\
\hline No. of reindeer /ha & 0.018 & 0.018 & 61 & 27 \\
\hline Ha/reindeer & 55 & 56 & & \\
\hline
\end{tabular}

Table 2: Number of members, reindeer and hectares in the studied samebyar, total and per capita. Source: The Sami Parliament (2014a, b, c, d; 2017). ${ }^{11}$

\footnotetext{
${ }^{11}$ The total number of reindeer in Sweden is 250,000 with 4,657 reindeer owners, an average of 53.6 per capita (The Sami Parliamant 2017). Reindeer herders are typically herding their own reindeer but are also herding on behalf of the extended family and other owners. Others also work with the herd to to different degrees and with different capacities - depending on need and the season. Most reindeer owners have fewer than 50 reindeer and few, less than a hundred, owns more than
} 


\section{Talma sameby}

Allas (Interview) described that the main activities affecting reindeer husbandry in Talma are tourism and forestry. Talma has experienced significant adverse effects of logging on their reindeer husbandry since the 1980s, when logging was mechanized and drastically scaled up. Although the forestry industry has claimed to have always coexisted with $\mathrm{RDH}$, which may have been true in Talma when the scale of operations was small and prior to mechanization, this was no longer felt to hold. In Talma, Allas described how the current scale of logging operations was perceived to negatively affect the reindeer in several ways. Allas went on to describe how clear-cutting of forests removes the trees together with the lichens (Usnea subflorida, Usnea hirt, Platismatia glauca, Bryoria capillaris, Evernia divaricata, Melanelia olivacea, Pseudevernia furfuracea) and other understory species, which the reindeer rely on for seasonal forage, especially in winter. Furthermore, ploughing of the land for reforestation changes the land in ways that makes it impossible for reindeer and herders' snow-scooters to navigate. Planting of foreign tree species (such as lodgepole pine, Pinus contorta) also prevents undergrowth. The consequence of these practices is that a newly cut forest area cannot be used for grazing for 5-15 years. Cutting techniques that drain the land and support lichen regrowth are preferred, however if an area becomes too dry it can cause loss of other reindeer forage species (Allas, Interview). Talma has formal rights to take part in the decisions concerning forestry, if the area to be cut exceeds four hectares. However, according to Allas, to avoid negotiating forestry planning decisions with the sameby, forestry companies commonly cut areas of less than four hectares in a serial fashion.

Allas stated that tourism encroaches on Talma's reindeer pastureland mainly in the form of recreational snow scooters use and dog sledding. ${ }^{12}$ Dogsleds are not subject to restrictions as they are not considered to be motor vehicles. Elaborating more, he explained that reindeer suffer from stress related to the scent and sound of sled dogs, which prevents them from grazing, resulting in miscarriages and abandoning their calves. Dogsled tracks also mislead the reindeer, as they tend to follow tracks and thus get split up and separated from the herd. The big tourist operators have fixed the tracks and stay away from the reindeer, whereas the smaller operators often approach them as a tourist attraction. Some dogsled operators come from elsewhere in Europe and only stay in the area during the tourist season. Allas added that these dogsled companies do not care; he emphasized that this activity is also so new that Sweden has not had the time to adapt to the growth of the sector. Increasing numbers of tourists visiting the Ice Hotel in Jukkasjärvi were also cited by Allas as a cause of disturbance to the Talma RDH.

Allas advised that another competing land-use that affects RDH in Talma is small game hunting and fishing. The areas where these activities are practiced coincide with good reindeer grazing areas, for instance where mushrooms grow. Access to such areas is essential for the reindeer to gain precious fat for the winter. Hunting dogs disturb them and prevent them from eating the mushrooms and gaining weight, resulting in economic losses for the herders.

New mining plans may also have the potential to significantly disrupt RDH, not only due to reduced access to pastureland, but also due to increased truck traffic, a major hazard for the reindeer when migrating (Allas, Interview). Talma, like Saarivuoma is one of the four samebyar where Esrange tests space rockets and the community receives a small annual compensation for the disturbance caused (Sveriges Radio 2013). Parts of Talma territory also belong to Abisko and Vadvetjåkka National Parks (The County Administrative Board of Norrbotten 2012).

\section{Gabna sameby}

Niia (Interview) explained that over time external influences have caused significant changes to the practice of RDH in Gabna with the most prominent disturbances caused by forestry, tourism, forest reserves, mining and prospecting. Niia was of the view that all these new income-generating activities in the area have

500 reindeer. The Sami Parliament estimates that a herder needs 500-600 reindeer to have a livelihood based solely on this activity. An estimated 2,500-3,000 Sami are dependent on reindeer herding for their livelihood. Most Sami in Sweden rely on other activities than herding for their primary income (The Sami Parliament 2017).

${ }^{12}$ Reindeer herders also use modern herding methods, such as snow scooters to monitor and muster reindeer. 
disturbed prime reindeer grazing pastures that are rich in lichen and mushrooms. Furthermore, they have also obstructed reindeer migratory routes and made seasonal passage more difficult.

Abisko National Park, the tourist centre, the 'Kings Trail' hiking trail which crosses areas close to Torneträsk, and the Abisko Research Station ${ }^{13}$ all have a slight impact on the sameby (see below). Furthermore, a railway line and a road constructed in 1986, constrain reindeer movement in the area; as does the expanding mining industry in Kiruna. The cumulative effects of geographically relocating the city of Kiruna is resulting in housing areas being built in the middle of reindeer migration routes (Kuhmunen, Interview).

Although Gabna is given opportunities to participate in consultations ${ }^{14}$ (samråd) in matters that concern their interests, their relatively remote location means that they are often not able to participate (Kuhmunen, Interview). Kuhmunen advised that it is extremely time consuming in these consultations for reindeer herders to seek complementary information to be able to support their claims against mining, forestry, tourism or other competing economic activity.

Niia (Interview) described how forestry causes considerable problems in Gabna. Modern forestry practices such as land preparation, dense tree planting and experimental planting of lodgepole pine (Pinus $\underline{\text { contorta) }}$ are partly to blame. These practices reduce the reindeer's winter-fodder and possible grazing areas because of the adverse effects they have on lichen growth and soil and snow quality. They also hinder herding, since land preparation for forestry create conditions that make use of snow-scooters difficult and dangerous. Furthermore, Gabna is also affected by new plantings and clear-cutting. Niia explained that forestowners commonly clear cut areas of less than four hectares to evade consultation requirements.

Niia also explained that to confront the various problems they are facing, all samebyar formed the SSR (see section 4). This has resulted in, among other things, the creation of cooperation committees that participate in public consultations.

Niia explained how mining has an increasingly negative impact on RDH in Gabna due to recent prospecting for minerals and opening of new mines. On mining prospects, Kuhmunen said, "Of all potential mining projects, only a part will become reality, but the feasibility studies themselves create environmental problems." In Gabna, the impression is that mining regulations favor the companies, while the RDH's concerns are not taken into consideration by the Mining Inspectorate of Sweden. As Niia (Interview) remarked, "When it comes to mining, we neither reach compromises, nor solutions". In Niia's experience, the state-owned LKAB (Luossavaara-Kiirunavaara AB; a high-tech ore processing company) is willing to find solutions, unlike the newer mining companies operating in the area. Supporting this view, Kuhmunen explained that Gabna was the first sameby to reach a general agreement with LKAB through consultation. Because of mining development, herders in Gabna have had to change their main migration routes every year and some routes are now completely closed (Niia, Interview). Furthermore, apart from mining itself, disturbance is caused by the operation of trucks to and from the mines, which creates considerable difficulties for reindeer to cross motorways; many getting killed.

Dogsledding is also a disturbance to reindeer herds in Gabna, since the reindeer follow the tracks left behind by sleds, scattering the herds. The presence of the Abisko tourist station in Gabna also means, apart from dogsledding, skiing, scooters, and other tourist activities (The County Administrative Board of Norrbotten 2012), and disturbances from hunting cabins and cottages.

\footnotetext{
13 Abisko Scientific Research Station offers research facilities from observation and monitoring to high-tech experimentation. It also provides accommodation and self-catering facilities for researchers visiting the station. Long-term datasets on meteorological monitoring, hydrology, water chemistry and flora and fauna among others have been collected at the station. It also hosts also the Climate Impact Research Centre (Swedish Polar Research Secretary 2017).

14 These are legally regulated consultations, demanded when a new project (mine, road, wind power station, etc.) may affect livelihoods. Private companies and the State have to inform the public about the project and how it will affect their livelihoods, considering as much as possible the interests of both parties. The right to negotiate on behalf of the local people is regulated in legal documents. (SFS 1979: 429; SFS 1998: 808; SFS 2010: 900; SOU 2007: 10).
} 


\section{Laevas sameby}

Kiruna, [the county] with its large and fast growing mining industry, urbanization and military shooting range, creates a bottleneck for the reindeer herders from Laevas when they move reindeer between summer and winter pastures (Partapuoli 2013, Interview). Ecoducts have been constructed for the reindeer to cross railways and roads, but crossing such narrow fenced areas is 'unnatural' for the reindeer. Partapuoli explained how increasing efforts are required from Laevas herders to support the movement of their reindeer herds. He argued that changes in forestry practices such as clear-cutting, ploughing and use of pesticides and fertilizers have been devastating to both RDH and biodiversity in the area. Lichen disappears with tree-cutting and ploughing, and an open landscape due to clear-cutting and soil treatment like harrowing, changes the microclimate in the area. Furthermore, fertilizers and pesticides change the flora and fauna and make it sterile. The lichen that is still accessible for reindeer freezes and becomes impossible for them to eat. Huge ditches of 1.5 meters deep and a few meters wide made by forest machines during the 1970s pose problems for reindeer herders when tracking their animals. In Laevas, these conditions make reindeer return to the autumn and spring pastures during winter, which has led to overgrazing of these areas. Partapuoli explained how the use of foreign fast growing trees like lodgepole pine may be useful for the logging industry, but they constrain the undergrowth (a source of forage for reindeer) and reduce biodiversity. As a result of these disturbances reindeer herders in Laevas must substitute winter grazing with fodder, which is labor-intensive and costly, and has been perceived as affecting reindeer health (Partapuoli 2013, Interview).

Tourist activities such as dogsledding and snow scooter traffic also disturb Laevas' reindeer during the late winter and early spring, which is during grazing and calving times (Partapuoli 2013, Interview). Reindeer herders in Laevas also have little opportunity to protect their herds from the growing population of large predators, which is related to the existing hunting restrictions in Swedish regulations. Partapuoli argued that these factors are currently limiting the viability of $\mathrm{RDH}$ and suggest a bleak future.

\section{Summary}

The qualitative results from the four samebyar are summarized in Table 3, which presents the factors influencing RDH as experienced by our informants. Through discussions with our informants we have compiled an ordinal estimation of the degree of negative impact for RDH for each sameby (1-3, from lesser to greater impacts). This approach indicates that the samebyar are affected differently with the following order of decreasing impact: Laevas, Gabna, Talma and Saarivuoma. The most significant effects are attributed to mining and logging. Additionally, predation was seen to pose considerable problems for RDH. Saarivuoma (located more to the north that the other three samebyar) is affected mostly by predation relative to the other impacting factors.

\section{Reindeer herding through the lenses of PE and SES}

\section{Political ecology analysis}

The PE analysis of the results shows that the problems experienced by the reindeer herders across the samebyar studied are common, with differences only to the extent that they are affected by the different encroachments. The samebyar are caught up in a web of conflicting social, ecological and economic interests, which has historical foundations, but is also firmly rooted in contemporary development trajectories. The incremental expansion of a broad range of capital intensive development activities has resulted in an accumulated encroachment at the landscape scale. This encroachment pattern has, over time, put increasing pressure on the RDH ecology by reducing the territory available for grazing and therefore placing constraints on reindeer herding livelihoods (see Figure 1). This is despite the sameby, since its inception in 1961 as a referral body, being able to sue in response to encroachments on reindeer herder land that result in disturbances to the RDH system (Beach 1981; Cramer 2003). The consequence of this has been the steady diminution of land use rights and access over time, away from RDH to other State sanctioned economic activities. 


\begin{tabular}{|c|c|c|c|c|}
\hline Factors impacting on RDH & Laevas & Gabna & Talma & Saarivuoma \\
\hline \multicolumn{5}{|l|}{ Mining } \\
\hline Operating mines and pits & 3 & 3 & 3 & 1 \\
\hline Mining prospecting & 3 & 3 & 3 & 1 \\
\hline \multicolumn{5}{|l|}{ Logging } \\
\hline Young forestry & 3 & 3 & 3 & 1 \\
\hline Clear-cut & 3 & 3 & 3 & 1 \\
\hline \multicolumn{5}{|l|}{ Tourism and recreation } \\
\hline Off-piste skiing & 2 & 3 & 0 & 1 \\
\hline Downhill skiing and infrastructure & 3 & 3 & 0 & 0 \\
\hline Dogsledding & 2 & 3 & 3 & 2 \\
\hline Scooters & 3 & 3 & 2 & 1 \\
\hline Hotels, cabins and Aurora Boreal & 1 & 3 & 1 & 1 \\
\hline Hunting and Fishing & 3 & 3 & 2 & 2 \\
\hline National Parks, Reserves and Research Station & 2 & 1 & 1 & 2 \\
\hline \multicolumn{5}{|l|}{ Others } \\
\hline Predators (bear, wolverine, etc.) & 3 & 3 & 3 & 3 \\
\hline Military Exercises (shooting fields) & 3 & 1 & 0 & 1 \\
\hline Esrange Space Centre & 0 & 0 & 2 & 1 \\
\hline National Parks, Reserves and Research Station & 2 & 3 & 1 & 2 \\
\hline Urban / Built-up areas & 3 & 3 & 1 & 1 \\
\hline \multicolumn{5}{|c|}{$\begin{array}{l}\text { Other encroachments/disturbances (source: interviews with P. Benson GIS and land-use officer and T } \\
\text { Kuhmunen, GIS-operator The Sami Parliament (GIS maps) }\end{array}$} \\
\hline Wind power & 1 & 1 & 0 & 1 \\
\hline Railway & 3 & 2 & 0 & 1 \\
\hline Powerline (High voltage several 100 meters wide) & 1 & 1 & 0 & 1 \\
\hline Roads & 3 & 3 & 2 & 1 \\
\hline
\end{tabular}

Table 3: List of impacting factors on RDH in the four study cases. Ordinal estimation of degree of negative impact for RDH according to the reindeer herder respondents only (1-3, from lesser to greater impacts).

This trend of diminishing access to, and control over 'suitable' grazing lands has created an ongoing contested landscape that forces reindeer herders to constantly adjust their practices to new and increasing forms of encroachment. Sami rights to herd reindeer have been progressively weakened through various historical State interventions. This has reproduced deeply entrenched cultural notions of the Sami reindeer herders as the quintessential ecological custodians, which potentially clouds or frustrates ambitions of economic development for other Sami not engaged in $\mathrm{RDH}$. While we recognize the importance of this, the analysis presented here is primarily concerned with encroachments on herding rather than a deeper exploration of Sami identity or indigenous rights, although we acknowledge that these concerns are intimately related.

\section{Encroachments on reindeer herding grazing land}

Present encroachments affecting the samebyar involve small and large-scale activities that are sources of proximate and distant social and environmental change. Encroachments of major significance for the samebyar are the large-scale industrial operations of forestry and mining, which are perceived by our reindeer herder informants as a major threat to herding now and in the future. 
Large-scale mining development, backed by international capital, either prospective or in operation was raised by several of the informants as either being a significant current problem or a significant looming threat to RDH practice in the region, which they felt they could do not much about. According to our informants, industrial forestry creates landscapes that are difficult for herders to move through and severely reduces foraging opportunities for reindeer, especially at critical times when fodder is scarce. Herders expressed concerns about industrial forestry operations affecting environmental conditions through the use of heavy machinery, expansive clear-cutting, pesticides and fertilizers use and by the introduction of foreign species, as well as degrading the biodiversity and landscape values of the region. These practices, it was argued, severely diminish or even eradicate the main winter fodder (lichen) for reindeer. During mining operations, the land is not available for RDH. Mining also fragments the pasture land and is commonly accompanied by intensive prospecting of areas in the search of more minerals for the global market. With these activities come new methods of intensive exploitation and associated infrastructure development to meet the industry's increased needs for new roads, energy, water and communication. Labor is largely supplied on a fly-in fly-out basis, often from abroad.

The Subarctic also attracts tourists from all over the world eager to enjoy 'exotic' attractions such as hunting, dogsledding or the internationally acclaimed Ice Hotel. Many of these activities are run by non-local residents. Our informants claim that these tourist operators tend to be ignorant of, and insensitive to RDH, causing further problems on the transhumance routes. The Swedish state has adopted an ambitious plan to increase tourism, which is likely to further adversely affect RDH (see section 4). Within this future scenario, cultural notions of the Sami reindeer herders as custodians of nature, promoted by tourism ventures, may also work to exploit the 'otherness' of the Sami by turning a dynamic and living culture into an essence and source of profit for others (Pettersson 2006).

\section{Conflicts}

Local conflicts in Norrbotten County are numerous and profound, involving not only many different economic interests and the reindeer herders, but are also permeating through local societies and among Sami themselves. Conflicts or confrontations were addressed at the Abisko Conference 2013. For example, Jonsson (an expert in the Mountain Management Nature Protection Unit, County Board Jämtland) framed conflicts in the following way: "we prefer to see them as challenges, not problems necessarily." At this conference consultation (samråd) and cooperation (samverkan) were the terms often used when describing interaction among stakeholders over environmental issues. In interviews, reindeer herders experienced consultation as a shallow techno-bureaucratic exercise, which could easily be controlled, shaped or even avoided by sectoral authorities (in the case of forestry). Furthermore, there was a clear view from informants that herders, either through their Sami organizations, or the Sami Parliament, have limited political or legal leverage to influence development planning of large-scale projects deemed to be in the national (or even regional) interest.

The insightful rhetorical phrasing of one of the interviewees from Laevas "We adapt, but is this good or bad?" expresses a concern about having to continually adjust herding practices in the face of the ongoing economic development, supported by the Swedish local and national authorities and dictated by global production needs, which herders are unable to influence or control. This suggests a subtle but systematic repression of RDH interests over time. It also suggests a feeling of exasperation because most, if not all informants, felt that they were being left without any alternative course of action. Clearly this response, conditioned through a history of unequal treatment by the Swedish state, cannot be interpreted as (willing) adjustment (or adaptation in SES terms) to changed environmental conditions, but a pragmatic response to the longer term accumulative effects of different types of economic development that have progressively enclosed the RDH commons.

\section{SES analysis}

In the analysis presented here, the SES approach focuses on the attributes of system components and processes (i.e., institutions, cultural traditions and practices as well as ecological structures and services) necessary for RDH as a livelihood within the case study area. In doing so, we engage with Ostrom's SES 
framework (2007) that suggests that the social-ecological system's outcomes (i.e. social and ecological performance) are influenced by the interaction between system components (i.e. resource systems, resources units, governance systems, and users). We build this analysis on the assumption that the current and possible future state of the reindeer herding SES is determined by (i) the nature of ongoing disturbance, and (ii) the systems' (in)ability to respond.

\section{Ongoing system disturbances}

From the interviews, a picture emerges of the reindeer herding SES facing disturbances related to competing land use and altered technology. A SES analysis treats disturbances as part of the set of independent variables, affecting the functioning of the SES (which are seen as the ultimate dependent variable). Apart from stressing the consequences of the disturbances for governance systems and users, our SES analysis points to the effect that disturbances appear to have on ecosystem services crucial to RDH, such as the production of mushrooms and lichens, the quality of snow and the number of predators. From these observations, these ongoing disturbances are affecting the performance of RDH (subsystems and components), negatively.

\section{The system's (in)ability to respond}

From the empirical work, it is difficult to estimate the exact nature and extent of the RDH strategies, but it appears that they mostly entailed adaptation strategies - i.e., routines and practices have been modified and system configuration somewhat (but not dramatically) altered. Examples of such strategies included, feeding reindeer extra fodder during winter, taking new migratory routes, moving reindeer by truck to pass obstacles, and changing grazing areas when food is scarce or the forest too dense or with too many ditches to be navigable by snow scooters. However, the adaptation observed may not be adequate to increase the resilience of the system to the degree that it can withstand current pressures - let alone the increase envisioned by reindeer herders and others. Feeding reindeer extra fodder during the winter increases costs, with consequences for profitability and the availability of savings. Similarly, taking new migratory routes depletes the stock of possible new routes (i.e., there is a limit to how often this strategy can be applied if the stock is not replenished). Both strategies diminish the buffer capacity that may be needed in the future, in case the disturbances exacerbate.

There is a mismatch of scale resulting from the lack of congruence between administrative and regulatory borders that affects different stakeholders (Cumming 2011; Veldkamp et al. 2011). This specifically relates to the interaction between land users in the drawing-up of land-use plans. The informants expressed concern that developing such plans will be interpreted, by other actors and the authorities, as defining where reindeer pasture must be placed. Reindeer herders need to constantly adapt (as they have always done) to variable biophysical conditions. Restricting movement to certain areas at certain times poses severe constraints on RDH practice (Holling and Meffe 1996; Horstkotte et al. 2014; Tyler et al. 2007). In the eyes of the Sami herders, information sharing and deliberation is currently not carried out in a way that it can be expected to influence outcomes.

We see little evidence of effective attempts to develop transformation strategies altering functional, structural, and feedback properties of the social-ecological system. Sami institutions for collective action such as the creation of a national organization (SRR), and the Sami Parliament do not seem to be addressing attempts to transform the system in such a way to mitigate the effects of the ongoing disturbances. Furthermore, institutional arrangements such as Sami participating in consultations with competitive landusers were largely regarded as non-functional by our informants. Concerns such as these, as well as past events, have worked to erode trust between land use actors as well as between the reindeer herders and the State. Building trust may require new kinds of institutions that better coordinate competing development activities, emphasize long-term engagement and distribute power-sharing among actors more evenly. 
In sum, the empirical data considered here suggests that (1) desperate attempts to adapt herding practices are being undertaken, which in the end are unlikely to pay off, and (2) modest attempts to reform institutional arrangements geared at improving information sharing and fostering deliberation and trust have not yet led to a more resilient RDH system.

\section{Comparing SES and PE in our empirical study}

\section{Nature and scale of $R D H$}

Our study shows that the two approaches differ ontologically concerning their understanding of RDH. PE tries to grasp a human activity resulting from the dialectical relationship with nature and other humans/social groups. For SES, RDH is a social-ecological system that reflects human's interaction with the ecological system.

The approaches differ epistemologically in their spatial and temporal understanding of RDH. In trying to provide a contextualized understanding of the ongoing large-scale encroachments upon the RDH territory and associated rights, in the PE approach, researchers analytically contrasted and interlinked categories such as 'local-global', 'small-scale-large-scale', 'traditional/pastoralist production-industrial/capitalist production', 'Sami-Swedish settlers', 'Sami-State.' These apparent 'binaries' represent opposite and conflicting interests in the struggle for the appropriation of land and natural resources, and provide key analytical insights into the power relations associated with the political economy of the region. In the SES analysis, researchers looked at the components of the system, their functionality and interaction between them. In the RDH case, the SES analysis highlighted misfits of scale, communication problems and lack of trust among actors involved in current resource management. While PE focused on the dialectics of the relationship between the past and the present and the local and the global system, SES was concerned with how parts of the system (components and process within the system's boundaries) worked together, analytically highlighting the effects on functionality of interaction problems.

PE analytically framed RDH within global patterns of economic development and renewed processes of capital accumulation. Encroachments were seen to a large extent as a result of the global supply and demand trends, guided by both domestic and international market forces. In this analysis, the connection between the reindeer herders and the ecosystem was seen to be subjected to on-going stress through diminishment of Sami grazing lands by historical and current encroachment processes. SES explicitly identified signals that indicated strategies of reindeer herders and samebyar, which were deemed to be unsuccessful. In contrast to PE, the role of the state and market, as well as the historical context, were not explicit in SES analysis. That said, the market is indirectly referred to in the SES analysis through 'increased RDH costs' and the importance of the historical and current role of the State is also obliquely referred to as the broker of trust, which is used as a key analytical concept.

\section{Conflict or consensus?}

The second important ontological difference relates to how the two approaches view conflicts. The PE approach sees regional development in $\mathrm{RDH}$ territory taking place under conditions of unequal power relations, and therefore consensus assumptions are not valid.

Conflicts, when acknowledged by SES, were tacitly subsumed under a management perspective, which seeks remediation by furthering collaborative processes in which win-win solutions are deemed to be possible. By contrast, the PE analyses did not see opportunities for transformation though the existing consultation institutions. It interpreted the governance mechanisms established by the State as aiming to further the penetration of development capital by eliciting consent rather than redressing unequal political and economic power in decision-making. In contrast, SES saw conflict resolution as a viable way forward, if enough time and effort were invested in building or regaining trust. In this analysis, the competing interests, conflicts, and mismatches of the system arose because different parts of the social-ecological framework are 'handled' separately, without an adequate understanding of the complex whole. These mismatches are both in spatial terms (administrative and regulative borders) and temporal (misunderstanding of the long-term time scale and 'slow' pace of RDH by new actors). For PE, strengthening reindeer herders' land rights was a 
possible pathway to safeguarding their interests and livelihoods, thus entailing a structural transformation that would redistribute power. SES posited that conflict resolution could be achieved through collaboratively reforming existing resource institutions to build trusting relations. This enhanced pluralism in decisionmaking would more likely deliver outcomes of optimal mutual benefit.

\section{Responses to changing socio-environmental conditions}

The final ontological difference between the perspectives is their view on reindeer herders' responses to changing socio-environmental conditions. The PE analysis saw Sami herders as being subjected to conditions (ongoing encroachments to reindeer grazing lands) which they could not influence and that adversely affected them.

For PE, 'adaptation' as it is used by SES, obscured the multi-scalar power relations that structured the 'need' for the reindeer herders to 'adapt.' While in the SES analysis, adaptation was seen as being able to preserve the 'identity' of the social-ecological system or support system transformation, in the PE analysis it is argued strongly that the political economy of 'adaptation' is unjust. In the PE account 'adaptation' is understood by examining the underlying (and here institutionalized) power relations which work to disadvantage some actor groups over others. SES saw adaptation as purposive responses enacted to maintain the ability of RDH to withstand current and future pressures (including strategies to increase the ability of transforming the system in a desirable way). In adopting this view of adaptation, SES acknowledged that the responses observed were likely to be ineffective in coping with disturbances to RDH. For PE, herders were forced to 'adapt' to economic and political conditions that they affect through the formal institutional arrangements available to them. Table 4 below summarizes the comparison between PE and SES as applied in this case study by the two approaches.

\begin{tabular}{|l|l|l|}
\hline \multicolumn{1}{|c|}{ Comparison/ Criterion } & \multicolumn{1}{|c|}{$\begin{array}{c}\text { Political Ecology Approach } \\
\text { (PE) }\end{array}$} & \multicolumn{1}{c|}{$\begin{array}{c}\text { Social-ecological Systems } \\
\text { Approach (SES) }\end{array}$} \\
\hline $\begin{array}{l}\text { Nature of RDH as a system, } \\
\text { including its temporal and } \\
\text { spatial boundaries and scale } \\
\text { (ontological/epistemological) }\end{array}$ & $\begin{array}{l}\text { A human activity in a dialectic } \\
\text { relationship with nature and other } \\
\text { humans/social groups. }\end{array}$ & $\begin{array}{l}\text { A human activity resulting from } \\
\text { human interaction with the } \\
\text { ecological system. }\end{array}$ \\
\hline $\begin{array}{l}\text { Puts geographic and time-specific } \\
\text { problems in larger scale economic } \\
\text { and historical perspectives, } \\
\text { emphasizing their dialectics or } \\
\text { mutual interdependence. }\end{array}$ & $\begin{array}{l}\text { Understands RDH as a social- } \\
\text { ecological system and analyses it } \\
\text { within these boundaries. Attention } \\
\text { is given to spatial and temporal } \\
\text { variability in disturbances and how } \\
\text { the system responds to change. }\end{array}$ \\
\hline $\begin{array}{l}\text { Conflict and consensus } \\
\text { (ontological) }\end{array}$ & $\begin{array}{l}\text { Inherent to social systems, } \\
\text { grounded in power relationships. } \\
\text { Consensus discourses obscures } \\
\text { asymmetrical power relationships. }\end{array}$ & $\begin{array}{l}\text { Conflict resolution is enhanced by } \\
\text { negotiation. Consensus can be built } \\
\text { by negotiation, trust and reform of } \\
\text { institutions. }\end{array}$ \\
\hline $\begin{array}{l}\text { Response/reaction to change } \\
\text { (ontological) }\end{array}$ & $\begin{array}{l}\text { Agency limited by coercive } \\
\text { alteration of social and economic } \\
\text { practices is the result of oppression } \\
\text { and unjust power structures; } \\
\text { adaptation might perpetuate these } \\
\text { structures rather than give } \\
\text { incentives to change them. }\end{array}$ & $\begin{array}{l}\text { Functional adaptation - a strategy } \\
\text { or actions taken to maintain or } \\
\text { increase the capacity to deal with } \\
\text { current and future change. }\end{array}$ \\
\hline
\end{tabular}

Table 4: Comparison of PE and SES approaches to RDH in the Subarctic Sweden based on the case studies. 


\section{Conclusions}

In this article, we have described the socio-environmental conditions of Sami RDH through the perspectives of PE and SES. We have also explored how the different underpinning ontological and epistemological assumptions of the two approaches lead to different interpretations of RDH.

The uniqueness of our study consists of applying PE and SES in the same empirical study and using the results to undertake a meta-analysis that compares the underlying ontologies and epistemologies of both empirical analyses. In doing so, we argue that the differences between these two approaches are not just theoretical, but they also have social implications in terms of how socio-environmental problems are framed, understood and addressed.

There are differences in the epistemological and ontological thinking of SES and PE that are significant, particularly around framing of the research phenomenon, agency versus structure, possibilities for consensus and the way that the two approaches differ in the privileging of social science versus ecological concepts. More specifically the way that PE and SES conceptualized conflict and responses to change in the RDH study led to three key differences. First, while PE examines the articulation between local and differently scaled structures which work to constrain and enable actors, SES placed analytical focus on localized institutions and individuals as the base for collective action to enhance institutional efficiency (e.g., solve communication, trust and misfit problems). Second, whereas PE considers local socio-environmental conditions, it does so dialectically by examining the role (and implications) of structural processes, particularly related to how the processes of capital accumulation and the role of the state work together to disadvantage particular groups' resource control, access and use. In SES, resilience is concerned with understanding the function, structure and feedbacks of the system where system resilience can be desirable or undesirable. There is a tendency to look for manageable solutions and to rely on the capacities of local/regional actors to redress functional shortfalls. Third, PE saw responses to change as coercive alteration of practices, with RDH unable to influence the developmental related causes. SES on the other hand saw responses to change as coping and adaptation, where strategies were taken to maintain the capacity of RDH to deal with current and anticipated future change. Underpinning this approach is an assumption that deliberation embedded in reform of existing institutions is a key approach to manage conflicts.

These results show how applying SES and PE analytical approaches to the same empirical phenomena lead to two contrasting interpretations that inform different imperatives and related courses of action to instigate change. PE, in questioning the reform capacity of existing institutional arrangement, infers a political solution, which would give recognition to reindeer herders' land rights, implying equitable handling of conflict and power struggles over natural resources. For SES, institutional reform to correct system mismatches and foster trust among actors through deliberation processes is the key means by which to decide among possible futures. However, for SES, ongoing adaptations, both in terms of $\mathrm{RDH}$ practices and institutional arrangements are currently insufficient to maintain the system's identity. This implies that without reforms there is likely to be a fundamental system change.

It is apparent from this study that ontological and epistemological disparity between the two approaches infer different courses of action to support the sustainability of RDH. This finding, drawn from one specific empirical study, is important for deepening our understanding of the bases of the ongoing debates between PE and SES. Particularly as this understanding relates to dealing with tensions between the State's role of protecting indigenous rights in the face of strong global economic forces constantly striving to maximize capital accumulation opportunities.

Consistent with our findings, Kull and Rangan argue that SES "nearly always targets policy-making" (2016: 78) and in doing so assumes that a deliberative consensus is both desirable and possible. In contrast, as this study has shown, PE sees this approach as subjugating the politics of redistribution and dissent. Thus, PE argues for a form of agonism in policymaking that more readily allows for political conflict able to give effect to redistribution of power and control over resources (Mouffe 2005). 


\section{References}

Adger, W.N. 2000. Social and ecological resilience: are they related? Progress Human Geography 24(3): 347364.

Adger, W.N. 2006. Vulnerability. Global Environmental Change 16: 268-281.

Armitage, D.R. 2007. Governance and the commons in a multi-level world. International Journal of the Commons 2(1): 7-32.

Beach, H. 1981. Reindeer-herd management in transition: the case of Tuorpon Saameby in Northern Sweden. Acta Univ. Ups., Uppsala Studies in Cultural Anthropology 3. Uppsala: Uppsala University.

Biermann, F., X. Bai, N. Bondre, W. Broadgate, C.-T. A. Chen, O. P. Dube, J.W. Erisman, M. Glaser, S. van der Hel, M.C. Lemos, S.Seitzinge and K.C. Seto. 2015. Down to Earth: contextualizing the Anthropocene. Global Environmental Change 39: 341-350. Academia

Brown, K. 2014. Global environmental change: a social turn for resilience? Progress in Human Geography 38(1): 107-117.

Bryant, R.L. 1998. Power, knowledge and political ecology in the third world: a review. Progress in Physical Geography 22: 79-94.

Bryant, R.L. and S. Bailey. 1997. Third world political ecology. London and New York: Routledge.

Carpenter, S., B. Walker and J. Anderies. 2001. From metaphor to measurement: resilience of what to what? Ecosystems 4: 765-781.

Cumming, G.S., D. Cumming and C. Redman. 2006. Scale mismatches in social-ecological systems: causes, consequences, and solutions. Ecology and Society 11(1): 1-20.

Cumming G.S. 2011. Spatial resilience: integrating landscape ecology, resilience, and sustainability. Landscape Ecology 26(7): 899-909.

Cote, M. and A.J. Nightingale. 2011. Resilience thinking meets social theory: situating change in socioecological systems (SES). Progress Human Geography 36(4): 475-489. Researchgate

County Administrative Board of Norrbotten. 2012. Facts about Norrbotten. Luleå: County Administrative Board of Norrbotten.

Cramér, T. 2003.Vinterstierna - Sameägt land och vatten med vinterbetsrätt. Samernas Vita Bok (SVB). Vol. 30.

CSD Conference. 2013. The intersection of society and nature in sustainability research, International research conference, October 1-3. http://www.csduppsala.uu.se/societynatureresearch [accessed March 2016]

Dagens Nyheter. 2016. Glädje bland samer efter tingsrättsdomen. [accessed February 6 2016]. http://www.dn.se/arkiv/dn-nyheter/gladje-bland-samer-efter-tingsrattsdomen/

Dictionary Reference. 2015. Encroach. [accessed 20 November 2015]. http://dictionary.reference.com/browse/encroach.

Duraiappah, A.K., S.T. Asah, E.S. Brondizio, N. Kosoy, P.J. O'Farrell, A.-H. Prieur-Richard, S.M. Subramanian and K. Takeuchi. 2014. Managing the mismatches to provide ecosystem services for human well-being: a conceptual framework for understanding the New Commons. Current Opinion in Environmental Sustainability 7: 94-100. Researchgate

Folke, C., S.R. Carpenter, B. Walker, M. Scheffer, T. Chapin and J. Rockström. 2010. Resilience thinking: integrating resilience, adaptability and transformability. Ecology and Society 15(4): 20.

Geological Survey of Sweden. 2017. Mineral Resources. [accessed April 5 2017]. https://www.sgu.se/en/mineral-resources.

Green, C. 2009. Managing Laponia. A World Heritage Site as arena for Sami ethno-politics in Sweden. Acta Universitatis Upsaliensis. Uppsala Studies in Cultural Anthropology 47. Uppsala.

Hafström, G. 1981. Inrymning Om skattefjällen i Jämtland och Härjedalen, Stockholm: Association for Swedish Cultural History and the Nordic Museum. Lund: Folklivsarkivet. 
Hall, R., M. Edelman, S.M. Borras Jr., I. Scoones, B. White and W. Wolford. 2015. Resistance, acquiescence or incorporation? an introduction to land grabbing and political reactions 'from below'. Journal of Peasant Studies 42(3): 467-488.

Heynen, N., J. McCarthy, S. Prudham and P. Robbins. 2007. Introduction: false promises. In Heynen, N., J. McCarthy, S. Prudham and P. Robbins (eds.) Neoliberal environments. London: Routledge. Pp. 1-22.

Holling C.S. 1986. The resilience of terrestrial ecosystems; local surprise and global change. In Clark, W.C. and R.E. Munn (eds.) Sustainable development of the biosphere. Cambridge: Cambridge University Press. Pp. 292-317.

Holling, C.S. and G.K. Meffe. 1996. Command and control and the pathology of natural resource management. Conservation Biology 10(2): 328-337.

Holmbäck, Å. 1922. Om Lappskatteland och dess historiska utveckling. Statens Offentliga Utredningar (SOU) 1922:10. Stockholm: Social Departementet.

Hornborg, A. 2009. Zero-sum world: challenges in conceptualizing environmental load displacement and ecologically unequal exchange in the world-system. International Journal of Comparative Sociology 50: 237-262.

Hornborg, A. 2017. Artifacts have consequences, not agency: toward a critical theory of global environmental history. European Journal of Social Theory 20(1): 95-110.

Horstkotte, T., C. Sandström and J. Moen. 2014. Exploring the multiple use of boreal landscapes in northern Sweden: the importance of social-ecological diversity for mobility and flexibility. Human Ecology 42(5): 671-682.

Jagers, S., J. Rockström and M. Widgren 2012. Cross-disciplinary environmental science? Perspectives from the natural and social sciences. The Stockholm University Environmental Social Science Seminar (SUES) held on 17 April 2012 at Stockholm University.

Janssen, M.A., Ö. Bodin, J.M. Anderies, T. Elmqvist, H. Ernstson, R.R.J. McAllister, P. Olsson and P. Ryan. 2006. Toward a network perspective of the study of resilience in social-ecological systems. Ecology and Society 11(1): 15.

Jerneck, A, L. Olsson, B. Ness, S. Anderberg, M. Baier, E. Clark, T. Hickler, A. Hornborg, A. Kronsell, E. Lövbrand and J. Persson. 2011. Structuring sustainably science. Sustainability Science 6: 69-82.

Karlsson, A-M. 2015. Beslut för långsiktig överlevnad: Värderingar, mål och beslut inom renskötseln. Ph.D. dissertation. Uppsala: Swedish University of Agricultural Sciences.

Khan, M.T. 2013. Theoretical frameworks in political ecology and participatory nature/forest conservation: the necessity for a heterodox approach and the critical moment. Journal of Political Ecology 20: 460472.

Kull, C.A. and H. Rangan. 2016. Political ecology and resilience: competing interdisciplinarities? In B. Hubert and N. Mathieu (eds.) Interdisciplinarités entre natures et sociétés. Brussels: PIE Peter Lang. Pp. 71-87.

Lansing, J.S. 2003. Complex adaptive systems. Annual Review of Anthropology 32(1): 183-204.

Leach, M. (ed.). 2008. Re-framing resilience: a symosium report. STEPS Working Paper 13. Brighton: IDS, STEPS Centre.

Lundmark, L. 1998. Så Länge vi har marker. Samerna och staten under sex hundra år. Falun: Rabén Prima.

Martinez Alier, J. 2010. Politicized nature: introduction. In Friman E. and G.L. Gallardo F. (eds.) Politicized nature. Global exchange, resources and power. Uppsala: Cefo Publication Series Number 2.

Merriam-Webster Dictionary. 2015. Encroach. [accessed 20 November 2015]. http://www.merriamwebster.com/dictionary/encroach.

Mining Inspectorate of Sweden. 2016. About the mining inspectorate. [accessed March 9 2016]. http://www.sgu.se/en/mining-inspectorate/about-the-mining-inspectorate.

Mouffe, C. 2005. On the political. London: Routledge. 
Nadasdy, P. 2007. Adaptive co-management and the gospel of resilience. In Armitage, D.R., F. Berkes and N. Doubleday (eds.). Adaptive co-management: collaboration, learning, and multi-level governance. Vancouver: UBC Press.

Naturvårdsverket (NVV). 2015. Magnificent mountain landscape. [accessed May 24 2015] http://www.miljomal.se/sv/Environmental-Objectives-Portal/Undre-meny/About-the-EnvironmentalObjectives/14-A-Magnificent-Mountain-Landscape

Naturvårdsverket (NVV). 2012. [accessed January 9 2013, no longer accessible]. http://www.naturvardsverket.se/Miljoarbete-i-samhallet/Sverigesmiljomal/Miljokvalitetsmalen/Storslagen-

Olsson, L., A. Jerneck, H. Thorén, J. Persson and D.O. Byrne. 2015. Why resilience is unappealing to social science : theoretical and empirical investigations of the scientific use of resilience. Science Advance 1 (4): 1.

Össbo, Å. and P. Lantto. 2011. Colonial tutelage and industrial colonialism: reindeer husbandry and early 20th-century hydroelectric development in Sweden. Scandinavian Journal of History 36(3): 324-348.

Ostrom, E. 2007. A diagnostic approach for going beyond panaceas. Proceedings of the National Academy of Sciences 104 (39): 15181-15187.

Ostrom, E. and J. Walker (eds.). 2003. Trust and reciprocity: interdisciplinary lessons from experimental research. New York: Russell Sage Foundation.

Pahl-Wostl, C., M. Craps, A. Dewulf, E. Mostert, D. Tabara and T. Taillieu. 2007. Social learning and water resources management. Ecology and Society 12(2): 5.

Peet, R., P. Robbins and M.J. Watts (eds.). 2011. Global political ecology. London: Routledge. Scribd

Pettersson, R. 2006. Ecotourism and Indigenous positive and negative impacts of Sami tourism tourism. In S. Gössling and J. Hultman (eds.) Ecotourism in Scandinavia: lessons in theory and practice. Wallingford: CABI Publishing.

Peterson G. 2000. Political ecology and ecological resilience: an integration of human and ecological dynamics. Ecological Economics 35: 323-336.

Peterson, G. and A. Hornborg. 2012. Grasping sustainability: a debate on resilience theory versus political ecology. Video: https://www.youtube.com/watch?v=D_NCSQ1qNac. Centre for Sustainable Development, CDS Uppsala, Uppsala University, Uppsala, Sweden. [accessed March 2016].

Resilience Alliance. 2015. Key concepts. [accessed August 4 2015]. http://www.resalliance.org/index.php/key_concepts.

Rogers, K.H., R. Luton, H. Biggs, R.O. Biggs, S. Blignaut, A.G. Choles, C.G. Palmer, and P. Tangwe. 2013. Fostering complexity thinking in action research for change in social and ecological systems. Ecology and Society 18(2):31.

Sami Parliament. 2013. Samefonden. [accessed 7 March 2017], https://www.sametinget.se/65187.

Sami Parliament. 2014a. Laevas. [accessedNovember 24 2014]. https://www.sametinget.se/8648.

Sami Parliament. 2014b. Gabna. [accessed November 24 2014]. https://www.sametinget.se/8587.

Sami Parliament. 2014c. Talma. [accessed November 24 2014]. https://www.sametinget.se/8560.

Sami Parliament. 2014d. Saarivuoma [accessed November 24 2014]. https://www.sametinget.se/8552 .

Sami Parliament. 2015. Samebyar. [accessed November 25 2015]. https://www.sametinget.se/samebyar.

Sami Parliament. 2017. Rennåring. [accessed March 6 2017]. https://sametinget.se/statistik rennaring.

Sandström, A. and C. Rova. 2010. Adaptive co-management networks: a comparative analysis of two fishery conservation areas in Sweden. Ecology and Society 15(3):14.

Schoon, M.L., M.D. Robards, K. Brown, N. Engle, C.L. Meek and R. Biggs. 2015. Politics and the resilience of ecosystem services. In: Biggs, R., M. Schlüter and M.L. Schoon (eds.). Principles for building resilience: sustaining ecosystem services in social-ecological systems. Cambridge: Cambridge University Press. Pp. 32-49. 
Semb, A.J. 2012. Why (not) commit? Norway, Sweden and Finland and the ILO Convention 169. Nordic Journal of Human Rights 2: 122-147.

SFS. 1979. Svensk författningssamling 1979:429 (Swedish Code of Statutes; Swedish law) Skogsvårdslag (Forestry Act).

SFS. 1992:1433. Svensk författningssamling 1992:1433 (Swedish Code of Statutes; Swedish law) Sametingslag. (Sami Parliament Act).

SFS. 1993. Svensk författningssamling 1993:36 (Swedish Code of Statutes, Swedish law) Lag om ändring i Rennäringslagen (1971: 437). (Change of Reindeer Herding Act, 1971: 437) .

SFS. 1998. Svensk författningssamling 1998:808 (Swedish Code of Statutes, Swedish law) Miljöbalken (Environmental Act).

SFS. 2010. Svensk författningssamling 2010: 900 (Swedish Code of Statutes, Swedish law) Plan och bygglagen (Planning and Building Act).

Sköld, P. 2011. Development, adjustment and conflict: the Sami and reindeer husbandry in Sweden in the light of political, social and economic changes. In Antonsson H. and U. Jansson (eds.) Agriculture and forestry in Sweden since 1900: geographical and historical studies. Stockholm: The Royal Academy of Agriculture and Forestry.

SOU 2006:14 Governmental green papers, Sami customary lands (Statliga offentliga utredningar, Samernas sedvanemarker). Government Offices of Sweden.

SOU 2007:10 Governmental green papers, Sustainable organization of the society with development power (Hållbar samhällsorganisation med utvecklingskraft, Ansvarskommitténs slutbetänkande). Government Offices of Sweden.

Svenska Samernas Riksförbund (SSR). 2012. Swedish Sami Association letter to the Minister of Rural Affairs, 25 June 2012.

Svenska Samernas Riksförbund (SSR). 2013. Om SSR. [accessed January 9 2013]. http://www.sapmi.se/om_0_0.html

Sveriges Radio. 2013. Ersättning för rymdstörningar. Sameradion, Sveriges Radio. [accessed January 17 2013]. http://sverigesradio.se/sida/artikel.aspx?programid=2327\&artikel=5412122

Swedish Polar Research Secretary. 2017. Abisko Scientific Research Station. [accessedMarch 2 2017]. http://polar.se/en/abisko-naturvetenskapliga-station/om-forskningsstationen.

Swedish Space Corporation (SSC). 2017. Launch Services. [accessed March 2 2017]. http://www.sscspace.com/products-services/rocket-balloon-services/launch-services---esc/launchservices-esrange-space-center.

Swedish Forest Agency. 2013. Renbruksplan. [accessed $\quad$ January 17 2013]. http://www.skogsstyrelsen.se/renbruksplan/.

Swedish Ministry of Enterprise, Energy and Communications. 2013. Sweden's Minerals Strategy - For sustainable use of Sweden's mineral resources that creates growth throughout the country. Stockholm: Governmental Offices of Sweden, Swedish Ministry of Enterprise, Energy and Communications.

Tyler, N.J.C., J.M. Turi, M.A. Sundset, K. Strøm Bull, M.N. Sara, E. Reinert, N. Oskal, C. Nellemann, J.J. McCarthy, S.D. Mathiesen, M.L. Martello, O.H. Magga, G.K. Hovelsrud, I. Hanssen-Bauer, N.I. Eira, I.M.G. Eira and R.W. Corell. 2007. Saami reindeer pastoralism under climate change: applying a generalized framework for vulnerability studies to a sub-arctic social-ecological system. Global Environmental Change 17(2): 191-206.

Veldkamp, A., N. Polman, S. Reinhard, and M. Slingerland. 2011. From scaling to governance of the land system: bridging ecological and economic perspectives. Ecology and Society 16 (1):1.

Västerbotten Investment Agency. 2015. National Strategy for Tourism and Travel 2020. [accessed November 20 2015]. http://viavasterbotten.se/sectors/tourism/overview/sweden/tourism-2020/.

Westley, F.R., O. Tjornbo, L. Schultz, P. Olsson, C. Folke, B. Crona, and O. Bodin. 2013. A theory of transformative agency in linked social-ecological systems. Ecology and Society 18(3):27. 
White, I and P. O'Hare. 2014. From rhetoric to reality: which resilience, why resilience, and whose resilience in spatial planning? Environment and Planning C: Government and Policy 32: 934-950. Researchgate

Widgren, M. 2015. Linking Nordic landscape geography and political ecology. Norsk Geografisk Tidsskrift Norwegian Journal of Geography 69(4): 197-206.

Widgren, M. 2012. Resilience thinking versus political ecology: understanding the dynamics of small-scale labour-intensive farming landscapes. In Plieninger, T. and C. Bieling (eds.) Resilience and the cultural landscape: understanding and managing change in human-shaped environments. Cambridge: Cambridge University Press. 